Article

\title{
Can Courts Make Federalism Work? A Game Theory Approach to Court-Induced Compliance and Defection in Federal Systems
}

\author{
Gemma Sala \\ Department of Political Science, Grinnell College, 1210 Park Street, Grinnell, IA 50112, USA; \\ E-Mail: salag@grinnell.edu; Tel.: +1-(641)-269-4880 \\ External Editor: William Ferguson
}

Received: 1 March 2014; in revised form: 20 October 2014 / Accepted: 31 October 2014 /

Published: 2 December 2014

\begin{abstract}
Few studies on federalism analyze the role of courts as safeguards of the federal arrangement, and those that do tend to be too optimistic about what courts can do. This article analyzes the effect of judicial review on the interaction between the central and a regional government in a federation in order to understand the conditions under which courts may or may not enforce compliance with federalism. It argues that politicians of either level of government anticipate the likelihood of a judicial challenge and an eventual veto, and it finds distinct equilibria in the interaction between central and regional governments (imposition, auto-limitation, negotiation and litigation). Only under auto-limitation do courts effectively prevent transgressions to the federal arrangement. In all other scenarios, defection may take place despite the presence of courts. These findings show that as the court's jurisprudence becomes more solid and defined, the chances for governments to successfully exceed their powers increase. Not only do transgressions take place despite the presence of the court, but because of it.
\end{abstract}

Keywords: federalism; constitutional safeguards; courts; judicial politics; game theory; constitutional politics; compliance; coordination

JEL classifications: C71; H77; K10; K41 


\section{Introduction}

Federations are contentious political settings. All levels of government find incentives to transgress the federal arrangement and to aggrandize their jurisdiction at the expense of other government units or threatening the viability of the federation itself (Bednar [1], Filippov, Ordeshook and Shvetsova [2], Bednar, Eskridge, Ferejohn [3]). Given such tendency to conflict, every federation has established courts to define the federal division of powers, and to veto any attempt from either level of government to exercise powers beyond their jurisdiction. Even Switzerland, which lacks judicial controls on legislative activity by virtue of the principle of parliamentary sovereignty, established a constitutional court for the sole purpose of maintaining federalism in check. Constitutional review is in fact a necessary component of federalism. The presence of courts is embedded in the definition itself. Unlike other forms of territorial decentralization, only in federal systems is the jurisdiction of each government unit constitutionally granted (Riker [4], Dahl [5], Linz [6]). Courts, as interpreters of the constitution, are instituted to make this guarantee effective when conflict arises.

Given their prominence, can courts restrain government units from behaving opportunistically and from adopting overreaching policies? Does the presence of constitutional review create incentives for a smooth functioning of the federal system? This article analyzes the strategies that politicians may develop around the threat of constitutional review in federal systems and assesses the extent to which the likelihood of a judicial veto encourages compliance or defection with the federation. I find that courts become effective safeguards of federalism when governments cannot anticipate judicial decisions. When they expect a judicial veto, the center and the regions will be able to strategize to avoid the court's involvement in order to be able to exercise power beyond their jurisdiction.

Most of the literature on federalism and its safeguards focuses on the ways in which political institutions, rather than judicial processes, protect the federal arrangement. ${ }^{1}$ When courts are considered, studies often explore whether courts should provide those safeguards from a normative standpoint (Wechsler [16], Kramer [8], Schapiro [17], Baker and Young [18]), or focus on particular instances in which the courts' veto has actually enforced constraints on governments in a federation (Ryan [15], Baker [19]). ${ }^{2}$ Few studies assess the extent to which those safeguards take place systematically. ${ }^{3}$

Important lessons can be learned from research on judicial politics. Constitutional review is known to play an informational role. As court rulings clarify constitutional ambiguities, reduce uncertainty and resolve misconceptions, they also reduce the likelihood that legislators will accidentally or opportunistically infringe on each other's powers (Rogers [4], Rogers and Vanberg [22]). In addition, judicial vetoes impose costs on overreaching legislation and leave behind a body of jurisprudence that facilitates the anticipation of those costs, creating incentives for compliance with the federal arrangement (Bednar [23], Stone Sweet [24,25], Vanberg [26,27]). Filippov, Ordeshook and Shvetsova [2] depict

\footnotetext{
${ }^{1}$ Elazar [7], Kramer [8,9], de Figuereido and Weingast [10], Watts [11], Bulam-Pozen and Gerken [12], Pursley [13,14], Ryan [15].

${ }^{2}$ Many of these studies conclude that judicial review has no effect on the allocation of powers between levels of government (Smith [20], Kramer [9], Cross [21]). But their analysis is bound to the case of the United States, since their arguments revolve around the Supreme Court's interpretation of specific clauses in the US constitution such as preemption, spending power or inter-state commerce clause, rather than the structural position of the court in the political system.

${ }^{3}$ Bednar [10] is a relevant exception.
} 
federal systems as prisoners' dilemma, in which all parties face incentives to defect from their agreement. The court's veto, considered to be exogenous to those original incentives, alters the pay-off structure to a point that compliance can be obtained. Only when courts are (or are perceived to be) biased or not independent from either side in conflict, is their success as safeguards of federalism diminished (Bednar [1,23]).

These views are, however, too optimistic about what courts can do to make federalism work. Transgressions to the federal arrangement abound despite the presence of constitutional review and of a body of jurisprudence that clearly establishes jurisdictional boundaries, even in countries with independent judicial systems. The German Constitutional Court found 77 legal norms to be (at least partially) unconstitutional for transgressing the federal arrangement between 1951 and 1980, Blair [28]. The Spanish Court found 488 violations between 1980 and 2008, and litigation continues to be a common resource to handle conflict between the central and the Autonomous governments despite the fact that the Court has produced more than 700 decisions on federalism. In the United States, litigation between the federal and state governments is less frequent, but quite prominent when it happens. In 2010, the federal government's challenge and subsequent Supreme Court's veto of relevant aspects of Arizona's immigration law made national headlines.

More surprisingly, transgressions are often not denounced in court and some even receive the consent of the government whose powers are trespassed upon. Such is the case, in Spain, of the 1998 Catalan language law, when the minority conservative government at the center agreed not to bring suit against it to the Constitutional Court in exchange for parliamentary support for its own legislation from the Catalan nationalist party (Miley [29]). Similarly, in 2006 none of the Spanish autonomies challenged the center's "dependency law"4 in Court despite the fact that, as experts agree, it infringed on the regions' autonomy. ${ }^{5}$ The central government went through several rounds of negotiations with the autonomies in order to prevent litigation and it introduced amendments that did not aim to preserve the federal division of powers, but rather to compensate the governments whose powers were infringed upon (Muñoz [33], Bedoya [34]). ${ }^{6}$ In the United States, several states enacted interstate water legislation, despite the fact that the Supreme Court previously established as a federal power by virtue of its authority over interstate commerce (Ryan [15], Tarlock [35]). Not only did Congress refrain from suing these states' legislation, but it also gave its explicit approval in order to prevent Courts from vetoing those state laws in the future (Tarlock [35]).

In light of such transgressions, why do central and regional governments pursue overreaching legislation despite the anticipation of a judicial veto? Why do governments denounce some transgressions but not others? What strategies are available to legislators in order to avoid judicial

${ }^{4}$ This 2006 central government law aimed to promote personal autonomy and provide assistance to dependent individuals. Ley 39/2006, de 14 de diciembre, de Promoción de la Autonomía Personal y Atención a las personas en situación de dependencia [30].

${ }^{5}$ The Catalan Advisory Council (Consell de Garanties Estatutàries [31]) deemed 35 of its 47 articles to be constitutionally questionable. Aja [32] agrees.

${ }^{6}$ A similar scenario in the United States is the interstate water legislation enacted in several states, which the Supreme Court had previously established as a federal power by virtue of its authority over interstate commerce (Ryan [15]). Not only did Congress refrain from suing these states' legislation, but it also gave its explicit approval in order to prevent Courts from vetoing those state laws in the future. 
scrutiny when they act beyond their jurisdiction? In addition, specifically, what role does the court play in these decisions? The extent to which courts are effective safeguards of federalism depends on the answer to these questions.

This article uses game theory to model the interactions between the central and a regional government in a minimal federation around the threat of judicial review. Their strategies are driven by the probability of a judicial veto, which is calculated by taking into account two main considerations. One, both the legislating and the opposing governments assess the chances that the court will uphold the law in question. Two, legislators will consider whether their opponents will actually challenge the law in court and their chances of preventing them from doing so. Similarly, potential challengers will take into account the payoffs of staying silent versus activating the judicial process. I find that the interaction of the two governments around these calculations produces four distinct outcomes: auto-limitation, litigation, imposition and negotiation. Only auto-limitation unequivocally prevents transgressing behaviors. Litigation also produces compliance with the federal system but does not prevent overreaching legislation from being enacted. Imposition and negotiation enable various forms of overreaching behaviors and extra constitutional agreements.

These findings are relevant for a number of reasons. One, they establish the conditions under which constitutional review can enforce compliance with the federation or transgressions against it. ${ }^{7}$ While we knew that these four behaviors exist, the model helps determine what caused one or another outcome and the role that the court plays in each of the different equilibria. The value of modeling the interactions defined in this paper is that it establishes the ways in which those four outcomes are interconnected and the necessary result derived from variation among the same few underlying factors. In doing so, it provides parsimonious explanations to otherwise complex and descriptive empirical scenarios. Second, the merit of this research is not only that it reveals that overreaching legislation can take place despite of the presence of judicial checks, but also that transgressions to the federal arrangement may occur due to the presence of constitutional review itself. In other words, the four equilibria may not be counterintuitive, but the factors that motivate them indeed are. Third, contrary to what the literature tends to argue, transgressions are not due to constitutional ambiguity or lack of information about the limits of each government's jurisdiction. Rather, the court's role in defining their constitutional limits is precisely what enables governments to develop successful strategies to avoid litigation and carry on overreaching legislation.

The first section of this article explores how governments can predict future judicial outcomes -and what happens when they cannot. The second analyzes the conditions under which opponents will challenge another government's legislation before the court. The third section develops a game theory model to find the outcomes of the interactions between these two players. The last section concludes.

\footnotetext{
${ }^{7}$ This article does not intend to determine every way in which federalism can or cannot be enforced. Indeed negotiations (or cooperation) between governments may take place under conditions that are not specified in the model. Here, my intent is to identify only the behaviors that derive exclusively from the court's presence, and the role that the threat of a judicial veto plays on each of them.
} 


\section{Anticipation of Judicial Outcomes}

Politicians know that courts are the final veto players in the political process. Their legislation is not safe just because it was approved by all necessary political forces. After members of parliament congratulate each other or presidential pens are distributed, constitutional review can still strike down their efforts. Therefore, legislators try to anticipate the probability that their bills, once approved, will surpass constitutional scrutiny if challenged (Stone Sweet $[24,25,36]$. However, how do they and their opponents assess the chances of a judicial veto? I contend that politicians predict court decisions by taking into account the court's position on an issue in the past, and the chances that it will maintain its position in the future if a similar law is challenged again. In an attempt of doing so, legislators behave as lawyers, or hire them instead, to review past opinions, research the state of the law and assess whether a new case falls within the scope of a previous decision. Once precedent and the court's jurisprudence informs them about the court's past position on an issue, they will also take into account the justices' preferences and the political environment to determine the likelihood that they will sustain the same position in the future.

As intuitive as this may sound, it presumes certain factors about the nature of judicial decisionmaking. One is that past decisions stick. The effect of prior judicial decisions on new ones derives from the nature of courts itself. Justices are bound in their choices because they are required to give principled reasons to the decisions they make and to justify departures from precedent (Shapiro [37], Bailey and Malztman [38]). Precedent becomes their positional starting point and determines how far courts can go in their rulings. ${ }^{8}$ Judicial decision-making places precedent and jurisprudence as the status quo and in a preferential position to affect future rulings. In addition, the legitimacy of courts as decision-making institutions depends on their ability to make new rulings consistent with old ones (Baum [40], Hansford and Spriggs [41], Bailey and Maltzman [38]). Unlike elected officials whose choices are justified by their representative character, the merit of judicial decisions is not found in their representativeness but on the principled logic of their argument. If their rulings only express will and opportunity their reputation would drop and their ability to affect the political process would be minimal. Giving up their interests for a principle today is a strategic decision to continue to have power tomorrow (as in Acemoglu and Robinson [42]). Moreover, judicial reliance on precedent, rather than political preferences or political constraints, generates political stability (Hayo and Voigt [43]). In the context of federalism, if preferences or interests bias the court towards regional governments, it may weaken the center to the point of making state building and coordinated policies difficult. If the court shows a bias towards the center, secessionism may develop (Bednar, Ferejohn, Eskridge [3]).

A second consideration is that, even as justices prioritize the consistency of the court's decisional record, there are still opportunities for the justice's personal preferences and values to be filtered into their decisions. If several interpretations consistent with the court's jurisprudence are available, or if precedent is weak or ill-defined, justices find opportunities to choose between different interpretations (Segal and Spaeth [39]). In either scenario, they can choose between alternative interpretations without putting the court's reputation at risk.

\footnotetext{
${ }^{8}$ This understanding shares with the legalist approach to judicial decision-making the argument that precedent holds a gravitational force, but disagrees with legalists in that its strength comes from the formal interpretational expertise that judges gain in law school. For a review of the legalist approach see Segal and Spaeth [39].
} 
Thirdly, the political environment may also play a role in the court's decisions. The court may succumb to political pressure or changing public opinion only if their legitimacy or the stability of the political system depends on it rather than on consistency with prior rulings (Vanberg [26,35], Helmke [44], Carubba, Gabel, Hakla [45], Ackerman [46]). If justices adhere to precedent to maintain the court's reputation and future power, they should also be attentive to political and social pressure when support for their decisions and for the court as an institution requires that they diverge from prior rulings or their own interpretations. ${ }^{9}$

From this perspective, the question is not whether precedent, preferences or political strategies determine judicial decisions (Segal and Spaeth [39], Epstein, Knight and Martin [48]). Rather, I understand courts as political institutions that operate within legal constraints. ${ }^{10}$ Judicial precedent marks the court's starting point before every decision; the justices' preferences and the political environment in which they operate determine the direction that the court's future rulings will take from there.

To the extent that politicians can assess the state of the law, the profile of justices, and the political environment their legislation may face if challenged, they should be able to anticipate the fate of their policies. However, this information is not equally available in every country. The ability of politicians to observe the conditions under which their policies will face judicial review depends on the institutional set-up of their political and judicial system. Several examples illustrate the differences in each system. Easy access to the court may translate into more litigation. The easier the access to the court, the more decisions the court will make, which in turns makes precedent more solid and predictable. Institutions such as certiorari in the United States or 'leave to appeal' in Canada could affect the predictability of the court's behavior. If the court has the ability to pick the cases it hears, it will make fewer decisions than if it were obliged to hear every case, and fewer decisions make precedent harder to predict. Where justices are appointed for life and are able to express dissenting opinions, their profile and decisional record will be more apparent than in systems where justices sit at the bench for short terms and where decisions are collegial. Variation in access, in the court's agenda setting powers and in the process of appointment indicates to politicians, indicate which the best sources of information are (precedent, profile of justices or political environment) to assess the court's future behavior.

\section{Anticipation of Judicial Challenges}

Legislators try to predict what the court is likely to decide, but this is not the only calculation they make. They also assess the chances that their policies will face judicial review in the first place. Since constitutional review only takes place by invitation, they will try to anticipate whether their opponents are able and willing to challenge their policies in court. ${ }^{11}$ Governments in a federation may find incentives to pursue legislation that violates the federal division of powers if they expect that affected governments will not denounce their behavior. However, why would the latter not challenge laws that

\footnotetext{
${ }^{9}$ In the United States, Chief Justice Roberts swinging decision regarding the Affordable Care Act (National Federation of Independent Business v. Sebelius, 567 U.S. 2012 [47]) may be interpreted in such terms.

${ }^{10}$ In contrast to strategic models of judicial decision-making, which only consider the political constraints that courts face in the decisions they make (Helmke [44], Carubba, Gabel, Hakla [45], Vanberg [35]).

${ }^{11}$ This consideration may not be relevant where one or another level of government does not have the ability to initiate judicial review, but for the purposes of this analysis I am assuming that both have equal access to challenge each other's legislation in court.
} 
curtail their jurisdiction when they expect the court to strike them down? This section explores the costs of challenging another government's policy and the conditions under which opponents are more or less likely to invite constitutional review.

Just as legislators are able to assess the likelihood of a judicial veto, challengers can do the same. The court's decisional history is an open record, which provides each level of government with identical information as to where the court stood in the past on an issue. For the purposes of this paper I will assume that legislators and their opponents are equally likely to make informed decisions regarding the state of precedent and jurisprudence on each single issue. Since both levels of government rely on the same information, a policy-maker's incentive to legislate under the expectation that the court will uphold its case should match its challenger's incentives not to take the case to court. Similarly, the legislators' reasons to refrain from enacting a law under the expectation of a court veto are the same reasons why its opponents could to challenge it if it became law.

Such symmetry of information should generate perfect coordination between legislators and challengers. If the court is expected to rule against them, transgressions to the federal arrangement would be prevented and litigation would be unnecessary. Yet, this is not the case. Both transgression and litigation over the scope of each government's jurisdiction are common practice in federal systems. One explanation is that the signals about the court's future rulings are not always clear. The court's decisional record and the aggregated policy preferences of justices may not always be known or clearly discernible. Another is that the court's expected decisions are not the only signal that the governments in conflict take into account to define their strategy. The costs of engaging in litigation also need to be assessed. If the costs of challenging a law in court are greater than the expected benefits from having it vetoed, its opponents may not pursue litigation even if they expect the court to side with them.

One obvious cost of litigation is the economic cost and time involved in it. Paying lawyers, writing briefs and waiting for the court to make a decision are resource-consuming issues. Some governments may have larger and stronger legal departments than others, depending on their budget and their willingness to invest in it, which create asymmetries in their ability to defend their jurisdiction. For the purposes of simplicity, the game developed in this paper assumes that asymmetric costs are not present - which is not a far fledged assumptions if we take into account that such costs drop as plaintiffs become repeat players, which central and regional governments in a federation are bound to be. ${ }^{12}$

The model developed in this article focuses on the political costs of litigation derived from electoral commitments and party hierarchies. To the extent that the electorate or their party may blame them for activating a process that ultimately invalidated the legislation they supported, potential plaintiffs may choose to keep conflict outside the court's reach. From this perspective, governments in a federation are more likely to initiate judicial review against the laws of another government when they are not politically aligned. If they are accountable to different constituencies and parties, they will not be punished for filing suit - they may even be compensated for it - making litigation politically costless and even beneficial. However, when electoral constituencies and/or party labels overlap, potential

\footnotetext{
12 Even where constitutional adjudication is led by individual plaintiffs — with expensive private counsel—rather than government institutions — which have lawyers on staff_- "organized rights advocates (...) develop a range of sources for support - comparable to the resources held by repeat players" (Epp [49], p.19).
} 
challengers may not be free to oppose the legislative initiatives of another government. Electoral punishment or party retaliation may introduce costs that trump the benefits from successful litigation. ${ }^{13}$

Table 1 represents the conditions that enable or prevent litigation between governments in a federation. Central governments are most likely led by state-wide parties - that is, parties whose constituency is spread throughout the country rather than localized in any of its regions. In contrast, regional governments are likely to be run by three different types of parties. First, regional parties, which tend to have a different electorate and party label from the center's. Their constituency is bound to the territory of the region and it rewards its government's ability to accomplish regional interests. Their representatives in the national parliament are considered as delegates of the region at the center and they tend to constitute a minority presence. Think of the Basque Nationalist Party in Spain or the Parti Québécois in Canada. When the central government is led by a state-wide party and the region by a regional one, they are independent from one another and free to challenge each other's legislation without fear of electoral retaliation or partisan reprimand. Each side can use litigation to protect their scope pf power: centralization or autonomy respectively.

Table 1. Type of party leading each of the governments in conflict, their ability to initiate judicial review and purpose of doing so.

\begin{tabular}{cccc}
$\begin{array}{c}\text { Governing party } \\
\text { at the center }\end{array}$ & $\begin{array}{c}\text { Governing party } \\
\text { in the region }\end{array}$ & $\begin{array}{c}\text { Government able to initiate } \\
\text { judicial review against the } \\
\text { other without retaliation }\end{array}$ & Goal of litigation \\
\hline State-wide party X & Regional party & Both & $\begin{array}{c}\text { Center: Centralization } \\
\text { Region: Autonomy }\end{array}$ \\
\hline State-wide party X & State-wide party $\neq \mathrm{X}$ & Both & $\begin{array}{c}\text { Center: Centralization } \\
\text { Region: Opposition }\end{array}$ \\
\hline State-wide party X & State-wide party X & Center & Center: Centralization \\
\hline State-wide party X & $\begin{array}{c}\text { State-wide party X } \\
\text { (X's electoral bastion) }\end{array}$ & Region & Region: Autonomy \\
\hline
\end{tabular}

Second, regional governments may be led by state-wide parties that form a minority at the center. Each level of government is led by the other's main state-wide opposition party-for example, the German SPD at the center and the CDU in the region. In this scenario, both the central and the regional platforms are independent from each other and have open access to the court. Unlike regional parties, these governments' constituencies are nation-wide and not necessarily circumscribed to a particular geographical area. In addition, the party's regional leaders are often subject to the strategies and policies of their party's headquarters, whose goal is to become the national majority and ultimately take over the executive at the center. When they succeed, the regional governments cease to be electorally independent from the center as they would share party label. Litigation in this case is a form of opposition politics (Blair [28]). It does not primarily aim to protect each government's jurisdiction. Rather, each government uses their central or regional platforms to annul in court legislation that they were unable to stop in each other's parliament.

\footnotetext{
${ }^{13}$ This perspective borrows from the notion that political parties can reward or please its members when they comply with the party's decisions and punish them when they cannot, thus facilitating policy coordination across the different institutions they control (Boyeller [50]).
} 
Third is a scenario in which both levels of government share party-label; they are led by the same state-wide party. In this scenario, litigation from the region against the center is less likely. This is either because they share policy preferences or because party discipline - especially common in parliamentary systems - deters its regional branches from pursuing local interests. ${ }^{14}$ If the regional governments are led by operative branches of the national majority party, penalties for challenging the center's overreaching policies in court are credible and their ability to protect their jurisdiction is low. The center is free to usurp regional powers without fear to face judicial review because it is costly for regions to initiate a challenge, whereas regions will be deterred from legislating beyond their jurisdiction because litigation is costless for the center and the court will veto. This scenario produces a tendency to centralization.

Fourth, there is a chance for the region to have the upper hand, even when both governments share party label. The region may be a strong hold of the party, it obtains a large portion of its overall electoral support and finds loyal and cohesive constituencies. Andalucia for the Socialist PSOE in Spain is an example; the voice of a United States Senator whose constituency is necessary to win a presidential election is another. ${ }^{15}$ In this scenario, the center becomes dependent towards the region and will be less willing to denounce this region's opportunistic legislation. ${ }^{16}$ It also enables the region to initiate judicial review against the center, as it will be less likely to retaliate against the region whose constituency it depends on to stay in power. This situation tilts towards decentralization.

\section{A Model of Court-Induced Interactions between Governments in a Federation}

According to the argument above, judicial precedent, the court's composition and party label inform the strategies that the different governments in a federation would follow in pursuing their preferred policies and protecting their scope of powers. Precedent and the bench's composition signal to legislators and potential challengers the likelihood of judicial success of their strategies. Party label (or electoral independence) determines the challengers' costs of involving the court in a dispute and informs legislators about the chances that their policies will face judicial review. This section introduces a game theory model that depicts the interactions between two levels of government in a minimalist federation and the pay-off structure derived from their calculations of the court's decision and the costs of litigation.

The minimal federation is any political system that meets the basic requirements of the minimalist definition of federalism; where there are at least two levels of government, each of which has final decision-making authority over a number of competencies, and where a constitutional or supreme court has binding power to assess the constitutionality of legal norms from either level of government (Riker [52], Dahl [5], Linz [6]).

\footnotetext{
${ }^{14}$ This category also includes situations in which governments may be led by different parties but are competing for the same constituency - for instance Democrat and Republican candidates in the United States competing for support and revenue from the same Super-PACs (Pursley [14]).

${ }^{15}$ Similarly, state governments in the United States have become strong lobbies in Congress by threatening the mobilization of public opinion against federal policy (Nugent [51]).

${ }^{16}$ This argument echoes Kramer's [8] thesis on the role of parties as safeguards of federalism. Regional control by state-wise parties can prevent federal aggrandizement. I add the caveat, however, that this is only possible when the regional branches of state-wide parties are electorally strong. When they are weak, party embeddedness in the region can however enable transgressions.
} 
I do not consider, however, any specific institutions common in federal systems that aim to foster cooperation between governments - such as a territorial senate, sectorial conferences or joint committees, regulatory descentralization - for two reasons. First, while every federation has at least two governments, a constitution and a court, not all of them adopted those cooperative institutions or the same ones (Sala [53]). Second, the model presumes that space for negotiation exists regardless of the type of institution in which it takes place and, since the purpose of this article is to assess the role of courts as safeguards of federalism, it focuses on instances in which cooperation takes place due to the threat of a judicial veto. ${ }^{17}$ While those cooperative institutions may help enforce federalism in and of themselves (Bednar [1], Watts [11], Kramer [9], Ryan [15]), ${ }^{18}$ the compliance they promote regardless of the court's presence is beyond the scope of this article.

The model also makes certain assumptions about the characteristics of the judicial review process, most of which are justified throughout the paper. Regarding access to judicial review, it assumes that both governments have equal formal standing before the court. They both can denounce each other's offensive legislation in court and the procedural rules to activate judicial review are identical. It also assumes that governments can bring cases to the court directly. They bring their complaints directly to the justices capable of assessing whether a law or an act of government is constitutional with binding effects throughout the country. ${ }^{19}$ In addition, the governments in conflict have similar financial means to engage in litigation or that those costs are fix or low. Regarding information, the model assumes it is perfect but incomplete. The courts decisional record and the profile of each justice is open to both players, which leads them to equal assessments about the likelihood of future court rulings. Finally, it also presumes that the court will make a decision on every case that is judicially challenged. The court has no agenda setting powers. These assumptions help simplify the model to the minimum number of players and institutional contingencies, which allows to explore the raw consequences of judicial review. The results obtained from this framework are a baseline to which the specific conditions of any particular system can be added.

If this minimalist federation and symmetrical system of judicial review are the board of the game, each level of government is a player. Consider G1 as the government that enacted (or plans to enact) a piece of legislation that is potentially beyond its jurisdiction, and G2 as the opposite level of government that is able to challenge it in court. The game consists of a simple two-shot interaction. First the legislator (G1) decides whether to enact a law (L) or abandon that policy $(\sim \mathrm{L})$. If it decides not to carry on with its

${ }^{17}$ This approach to federalism tries to get around the prevalent dichotomy between dual versus cooperative federalism (or judicial versus cooperative) — see Schapiro [17] for an overview of both approaches and a defense of the latter. Litigation and cooperation are not understood here as the result of the institutional design of a given federation, but as behaviors that governments in a federation engage in, depending on which best suits their interests. Rather than being constrained by the environment in which they find themselves, governments choose one or another outcome strategically. It is not clear why they would negotiate an agreement just because a certain institution is in place if they expect litigation to produce more beneficial results.

${ }^{18}$ Some of these institutions only facilitate compliance by creating opportunities for a government to threaten with uncooperative behaviors, as is a regional government's use of regulatory power to resist federal policy where the administration of federal laws is decentralized (Bulman-Pozen and Gerken [12]).

19 This prerogative is commonly exercised in European concentrated systems of judicial review. While it also exists in American de-concentrated systems, it is less often used due to presence of an alternative route to constitutional review through individual complaints originated in lower courts. 
policy, the game ends. If it legislates, the other government (G2) has a chance to challenge that act or statute $(\mathrm{C})$ before the constitutional court, or not to challenge it $(\sim \mathrm{C})$. If this government decides not to initiate judicial review, the game ends. If it involves the court, the legislating government may try to engage in negotiations $(\mathrm{N})$ with its challenger in order persuade it to remove the case from the court's docket. Otherwise it too ends the game by waiting to see what the court decides $(\sim N)$. Finally, the challenger may accept to negotiate (A) or refuse to do so $(\sim \mathrm{A})$ and maintain conflict on judicial grounds - see Appendix for a representation of this game depicting these interactions and resulting payoffs. Negotiations may involve changes in the policy in question to make it more acceptable to the challenger. Alternatively they may involve logrolling, by which the challenger abandons litigation in exchange for the legislator's support for policies that the challenger may want to pass and that also run the risk of being vetoed by the court. From this perspective, agreement between plaintiff and defendant does not necessarily imply compliance with the federal division of powers. It leads to mutually accepted transgressions, instead.

The factors leading the course of action of each player are the predictability of the court's decision (based on precedent and judicial composition) and their perception of their opponents' ability to engage in litigation (based on electoral — or party_independence). The probability of these factors generates different environments in which politicians make their legislative choices. If the court is expected to uphold a given law, the legislator (G1) is in a strong position and will have incentives to carry on with legislation regardless of the relative independence of the opposite government and its ability to challenge it in court-boxes 1 and 2 in Table 2. This is so because the chances of a challenge and judicial veto are low. Since the court is expected to side with the legislator, its opponent (G2) is unlikely to take it to court even if the costs of starting litigation are low.

Table 2. Relative strength of each government in conflict.

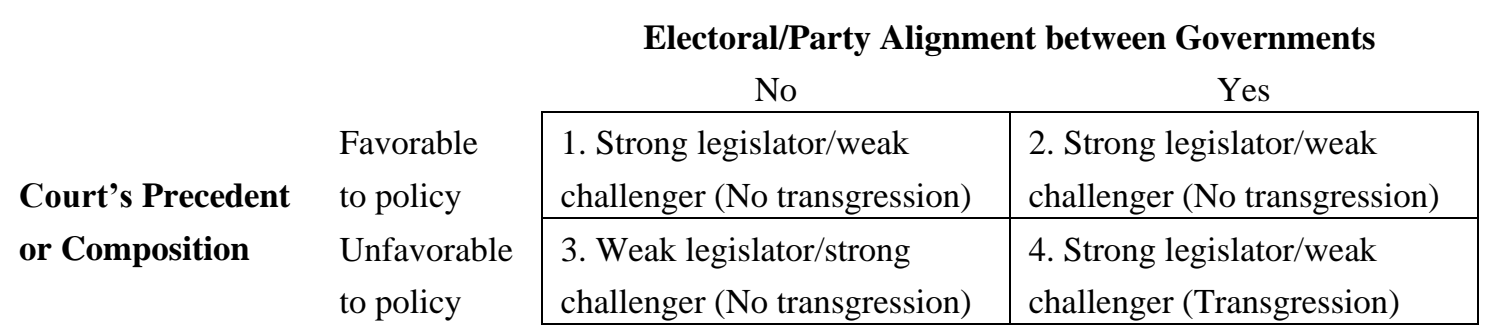

Strategies change when the court is expected to veto the law in question. If the governments in conflict have independent constituencies or do not share party label, ${ }^{20} \mathrm{G} 1$ will not be able to impose silence on their opponents, and will find itself in a weak position vis-à-vis likely challengers_-box 3. When this happens, G1 will have to find a way around the court by exercising "auto-limitation" - constraining their preferences and enacting laws that comply with the court's interpretation of the federal division of powers and thereby avoid a judicial veto - or through negotiation in order to persuade G2 against involving the court. Alternatively, if the party or constituencies of both governments are aligned, the offensive policy may be supported by shared constituencies or by critical sectors of their own party, which may deter challengers from inviting constitutional scrutiny-box 4. G1's ability to silence its opponents

${ }^{20}$ Alternative factors considered to establish dependency between the two levels of government (such as Kramer [9], Pursley [14], Nugent [51], Bulman-Pozen and Gerken [12]) could be replaced in the model in lieu of my choice for electoral or party overlap, yielding the same results as the model developed here. 
creates a window of opportunity for unconstitutional legislation to be enacted. Even when the court is expected to veto a policy, legislators find ways to deter a challenge and get away with their transgressions.

If legislators and challengers knew in which of these four environments they operate at all times, their expected behaviors would be straightforward. G1 and G2 indeed may know which environment they are facing regarding party alignment. They are generally aware of their electoral and partisan ties. They know whether their strength in government depends on the success of their party at the central or regional level, and are capable of predicting if the government whose legislation they challenge is likely to retaliate. However, their information about precedent and about the sitting justices' willingness to maintain it is not as clear. The proximity of a new case to an old decision is not known and can be assessed at most. Similarly, the collegial decision that aggregates the preferences of the sitting justices may take unexpected turns. As a result, legislators and their challengers cannot perfectly anticipate the court's future rulings.

The uncertainty about the court's future behavior places both players in a position of incomplete information about the environment in which they make their choices. They cannot be certain that the court will support their side; they can only assess the probability with which it may happen. The probability that the court will veto a given policy is represented by $p(0,1)$. A high $p$ implies that both players believe it is highly likely that the court will consider a policy to be unconstitutional if it is challenged. In other words, the court will rule against the law and in favor of G2. A low $p$ means that legislators and challengers expect the court to side with G1, uphold the policy, and consider it to be in agreement with its interpretation of the federal division of powers.

The last components of the game that need to be specified are the pay-offs associated with each government's strategy. The legislators' preferences are a function of four components. The expected benefit of passing a certain law is captured by a policy payoff of $\alpha>0$. The legislature reaps this benefit every time their policy overcomes a judicial veto- either because the challenger decides not to take the case to court, or because the court decides that the challenged policy is in agreement with the constitution. If the expected outcome leads to negotiations, the legislator's payoff will be $n_{l}$. This parameter includes the benefits from having been able to enact their legislation minus the costs of negotiation (it could alternatively be understood as $\alpha-n_{1}$ ). By definition, $\alpha>n_{1}>0$ - otherwise the legislator is better off giving up its piece of legislation completely.

If a challenge arises against a policy and the court upholds it, the legislator (G1) also reaps the benefit of having received judicial backing for its policies $(b>0)$. This benefit can be interpreted in many ways. It may send the signal to its electorate that its actions are legitimate (Vanberg [24]). However, this benefit is contingent upon the visibility of the case and people's awareness of judicial outcomes. The public may like or dislike a policy, but it cares less or knows little about who enacted or implemented it and who is to receive credit or blame for it (León Alfonso [54]). Therefore, I think that this benefit is best understood as the constitutional endorsement or recognition of G1's jurisdiction. Since judicial decisions on federalism include an assessment of the extent of each government's scope of powers, rulings in favor of a given policy not only enable a government's legislative initiative, but also set a precedent that grants jurisdiction and legitimizes future policies on that given policy area. 
Similarly, this benefit turns into a cost $(c)$ if the court decides that the legislator exceeded its prerogatives. ${ }^{21}$ This cost could derive from the fact that losing in court signals that it tried to implement overreaching policies and violated the federal arrangement. However, following the same rationale as before, I consider it to symbolize that G1 also has to deal with a court decision that sets a precedent that narrows its ability to legislate on a particular policy area in the future. Including the cost $c$ in the model helps explain why legislators (and challengers, as depicted below) will not try their luck in court. If there are added costs to a judicial veto, G1 will refrain from pursuing overreaching legislation when they expect that it will be challenged. If such costs did not exist, judicial vetoes would only preserve the status $q u o$ and legislators would pursue overreaching policies, even if they know they will be challenged, since there is nothing to lose.

There are also four components of the challenger's (G2) payoffs. The benefit of having the court veto a policy that infringes on its scope of powers and constitutionally endorses the challenger's jurisdiction into the future is represented by $j>0$. This benefit turns into a cost $(k)$ if the challenge fails and the court's ruling restricts the challenger's powers in the policy area under review (note that $j$ and $k$ for G2 follow the same logic as $b$ and $c$ for G1). The cost $k$ makes challengers less likely to dispute a case which they expect to lose. ${ }^{22}$ In addition, challengers also face the cost of retaliation inflicted by the legislator (or its electoral supporters) for challenging its policies and/or for disagreeing with the party's hierarchy. ${ }^{23}$ Let the cost be $h>0$. Since this cost depends upon the subordinate status of the challenger vis-à-vis the legislator, it will be weighted by $i(0,1)$. If the challenger is electorally independent, $i=0$ and the cost of retaliation will not be considered. Finally, similarly to the legislating government's payoffs, the challenger enjoys a benefit of $n_{2}>0$, when the final outcome involves negotiations.

\section{Predictions of the Model}

As the perception that the court will veto a policy increases, the environment will favor the challenger. If the court is rather expected to uphold the policy, the environment strengthens the position of the legislating government. The equilibrium predictions of the model depend on whether this joint probability falls below or above certain indifference thresholds, which follow-see Appendix for a representation and proof of the game.

For the policy-making government (G1), the legislative threshold (TL) is:

$$
\mathrm{TL} \equiv(\alpha+b) /(\alpha+b+c) .
$$

Given that $p$ represents the probability that the court will veto the law, and thus side with the challenger, values of $p$ below this threshold imply that the enacting government will legislate. This is because as the court is less likely to veto, the more comfortable G1 is to legislate. Values of $p$ that are above this threshold will lead this government not to legislate. The cost of having the court declaring that a

\footnotetext{
21 The cost of losing jurisdiction on a particular policy area could be expressed as $-b$. The benefit of power-enhancing jurisprudence can be assumed to be of the same size as the costs of having rulings restricting one's powers. I choose to use different symbols to express this cost and this benefit so that the factors determining the conditions under which governments chose a strategy or another are more clearly represented.

${ }^{22}$ Since the law they oppose is already enacted and they were unable to stop it during the legislative process, challengers are often expected to have nothing to lose from initiating judicial review (Bednar [23], Filipov, Ordeshook, Shvetsova [2]).

${ }^{23}$ This is a well-known scenario in parliamentary, multiple member district democracies.
} 
particular aspect of a policy area is outside the legislator's jurisdiction $(c)$ is in the denominator, indicating that as this cost increases the threshold lowers. That is, as the costs of unfavorable jurisprudence increase, the less likely the legislating government will be willing to risk its policy being challenged and vetoed.

A government that wants to enact a certain policy will offer negotiations to governments that (threaten to) challenge it in court if the likelihood of a negative ruling ( $p$ ) falls above the following negotiation threshold:

$$
\mathrm{TN} \equiv\left(\alpha+b-n_{1}\right) /(\alpha+b+c) .
$$

When $p$ is believed to be below this threshold, the legislator will not offer negotiations and, in the event that a challenge takes place, will wait for the court to decide. In other words, the costs of a judicial veto $(c)$ and the expected benefit of a negotiation $\left(n_{1}\right)$ will not be sufficiently large to encourage G1 to promote negotiations in order to avoid litigation. As the cost $c$ and the benefit $n_{1}$ increase, this government will find incentives to by-pass the court and open negotiations in the political arena. Note that the threshold to negotiate (TN) is the same as the threshold to legislate (TL) minus the benefit of negotiation - in the numerator. Therefore, TN < TL by definition. This implies that if the probability of a veto $(p)$ is lower than TN, the government will legislate and not offer negotiations. If $p$ lies between TN and TL, it will legislate but offer negotiations; and if $p$ is above TL (and TN by definition) it will not legislate and negotiate.

For the challenging government (G2), the threshold to challenge is:

$$
\mathrm{TC} \equiv(k+h i) /(j+k) .
$$

When the likelihood of a constitutional veto against another government's policy $(p)$ is above this threshold, the G2 will challenge. When $p$ is below the threshold, it will refrain from taking G1's policy to court. To make sense of this threshold, when the expected punishment for challenging $(h)$ goes up and the benefit of a judicial veto on unwanted policies $(j)$ lowers, the threshold (TC) becomes higher. This implies that the challenging government will want to make sure that the court is on its side before it invites the court to review a case. Note also that $h$ is weighted with $i$, so that when these two governments are electorally independent $(i=0)$, the cost of retaliation for having challenged G1's policies disappears, which in turn lowers the threshold to challenge.

Finally, when the legislating government offers negotiations, the challenger will agree to bargain and remove the case from the court's docket only if the probability of a favorable court decision against the challenged policy is below the following threshold:

$$
\mathrm{TA} \equiv\left(n_{2}+k+h i\right) /(j+k) .
$$

If $p$ is perceived to go below this threshold, G2 will accept negotiations. The logic is now similar to what we described above, for G1. TA contains the same information as TC plus the expected benefit of negotiations on the numerator. As the payoffs of accepting to negotiate increase, the threshold becomes higher and the challenger will be more willing to negotiate than to litigate. TA is by definition higher than TC-because $n_{2}>0$. Therefore, if the prospects of a court veto are above TA, the challenger will keep the case in the court and will not accept negotiations. If it is between TA and TC, this government will pursue litigation unless negotiations are offered. Contrary, if $p$ is below TC, the challenger will refrain from involving the court—see Figure 1 for a representation of G1's and G2's strategies. 
Figure 1. Predicted strategies derived from the interaction between G1 and G2.

Strategies for G1 (Legislator)

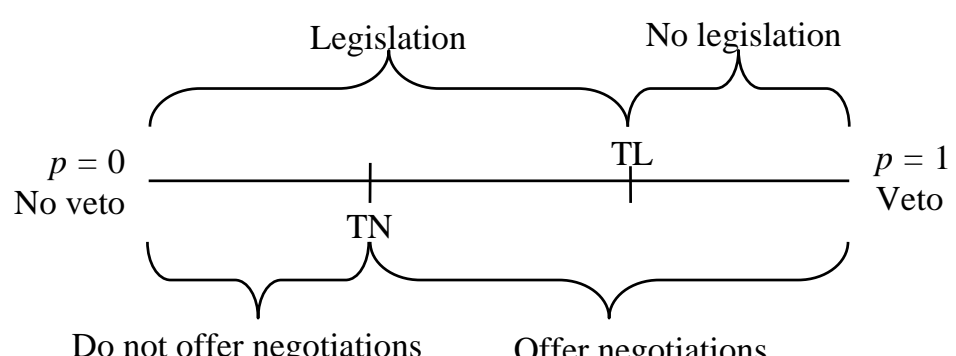

Do not offer negotiations $\quad$ Offer negotiations

Strategies for G2 (Challenger)

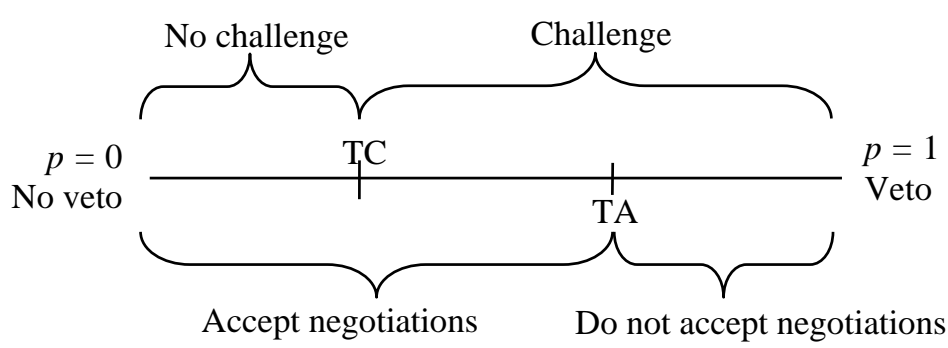

Note: The thresholds for each government are placed symmetrically for simplicity, their position actually depends on the size of the pay-offs contained in each threshold.

The combination of the thresholds that guide the strategies of each of these two actors at each given stage, provide six equilibria, that can be presented in four categories respectively identified as imposition, auto-limitation, negotiation, and litigation in reference to the types of strategy that they encourage.

\subsection{Imposition Equilibrium}

In this situation, the legislating government will be able to impose its policy on another government, regardless of whether the latter supports it or not. One reason for the success of legislation is that the parties in conflict believe that the court will uphold it, which makes opponents refrain from involving the court ( $k$ is too high). In this scenario, legislation is perceived to be within the boundaries of the enacting government's powers, and in compliance with the constitutionally defined, and judicially interpreted, federal division of powers. Alternatively, imposition may also take place if opponents are deterred from initiating litigation even if they predict a court's veto. If their constituency supports the policy they intend to challenge or if the legislator can impose a sufficiently large punishment for activating judicial review ( $h i$ is too high), challengers will not denounce the legislator's transgressions.

Equilibrium A: For $p<\mathrm{TC}$ and $p<\mathrm{TN}$ (and by definition $p<\mathrm{TA}$ and $p<\mathrm{TL}$ ), the following strategy profile constitutes a Perfect Bayesian Equilibrium:

Legislating government: $\mathrm{SG} 1=\{\mathrm{L}, \sim \mathrm{N}\}$

Challenging government: $\mathrm{SG} 2=\{\sim \mathrm{C}, \mathrm{A}\}$ 


\subsection{Auto-Limitation Equilibrium}

In this scenario, the legislator decides to give up its attempt to legislate because the likelihood of a judicial veto is sufficiently high to encourage its central or regional counterpart to engage in successful litigation. This equilibrium is more likely as the challenger costs of engaging in judicial review are low ( $h i$ is small). This combination of strategies makes legislators abandon overreaching policies and is the only scenario in which the presence of a constitutional court enforces compliance with federalism.

Equilibrium B: For $p>$ TA and $p>$ TL (and by definition $p>$ TC and $p>\mathrm{TN}$ ), the following strategy profile constitutes a Perfect Bayesian Equilibrium:

Legislating government: $\mathrm{SG} 1=\{\sim \mathrm{L}, \mathrm{N}\}$

Challenging government: $\mathrm{SG} 2=\{\mathrm{C}, \sim \mathrm{A}\}$

\subsection{Negotiation Equilibrium}

In this situation both governments agree to by-pass the court. They prefer to arrive to an agreement in the political arena and not invite the court to resolve the conflict. For this equilibrium to take place, G1 needs to have a very strong preference to legislate on an issue that is known to be constitutionally beyond its scope of power ( $\alpha$ is large) and the court is very likely to turn it down ( $p$ is high). Under these conditions, the legislator prefers to reach an agreement with its potential opponents, even if it implies reducing its payoff from $\alpha$ to $n_{1}$. It may agree to share $\alpha$ with its opponents, or decide not to challenge its opponent's own overreaching policies. In the latter scenario both governments obtain the benefit of their legislation $\alpha$ when they legislate minus the costs of the transgressions they have agreed to accept. Situations like this are the most interesting and unaccounted for in the literature. ${ }^{24}$ They underscore the limitations of judicial review as a mechanism to enforce federalism. Rather than promoting compliance with federalism, the threat of a judicial veto in this scenario generates situations that encourage defection from the federal arrangement.

Equilibrium C: For TC $<p<\mathrm{TA}$ and $\mathrm{TN}<p<\mathrm{TL}$, the following strategy profile constitutes a Perfect Bayesian Equilibrium:

Legislating government: $\mathrm{SG} 1=\{\mathrm{L}, \mathrm{N}\}$

Challenging government: $\mathrm{SG} 2=\{\mathrm{C}, \mathrm{A}\}$

\subsection{Litigation Equilibria}

Under the conditions specified below, federal disputes will be dealt with in court. The legislator will enact its preferred policy, its opponents will challenge it and the court will determine whether the policy is in agreement with the constitutional division of powers. Negotiations are not possible because at least one of the two governments is not interested in negotiation. This situation is more likely to occur when the position of the court on an issue is ambiguous $(p=0.5)$. Such ambiguity may lead governments to assign different probabilities to their payoffs and making them more likely to disagree about their need

\footnotetext{
${ }^{24}$ Vanberg [25] hints at the theoretical possibility that by-passing a court's decision might be an expected outcome in legislative-judicial interaction.
} 
to cooperate with one another-by not engaging in opportunistic behavior (auto-limitation), not challenging potential transgression (imposition), or negotiating.

Equilibrium D: For $p<\mathrm{TN}$ and $p>\mathrm{TA}$, the following strategy profile constitutes a Perfect Bayesian Equilibrium:

Legislating government: $\mathrm{SG} 1=\{\mathrm{L}, \sim \mathrm{N}\}$

Challenging government: $\mathrm{SG} 2=\{\mathrm{C}, \sim \mathrm{A}\}$

Equilibrium E: For $p<\mathrm{TN}$ and $\mathrm{TC}<p<\mathrm{TA}$, the following strategy profile constitutes a Perfect Bayesian Equilibrium:

Legislating government: $\mathrm{SG} 1=\{\mathrm{L}, \sim \mathrm{N}\}$

Challenging government: $\mathrm{SG} 2=\{\mathrm{C}, \mathrm{A}\}$

Equilibrium F: For TN $<p<\mathrm{TL}$ and $p>\mathrm{TA}$, the following strategy profile constitutes a Perfect Bayesian Equilibrium:

Legislating government: $\mathrm{SG} 1=\{\mathrm{L}, \mathrm{N}\}$

Challenging government: $\mathrm{SG} 2=\{\mathrm{C}, \sim \mathrm{A}\}$

Figures 2 and 3 graphically represent this argument. They illustrate the sectors along $p(0,1)$ in which all four equilibria take place. When the thresholds of both governments are placed symmetrically meaning that the costs and benefits from legislating and litigating respectively and/or their perception of the probability of a veto are identical-litigation does not take place (Figure 2). The court's actual intervention is unnecessary to address federal conflict. Only if the thresholds are asymmetrically located-governments obtain different rewards from their behavior and/or they disagree about their chances in court - is there room for litigation (Figure 3). In this scenario, the court has a chance to define the federal arrangement. 
Figure 2. Equilibria resulting from the interaction between G1 and G2, when both predict the same probability of a judicial veto.

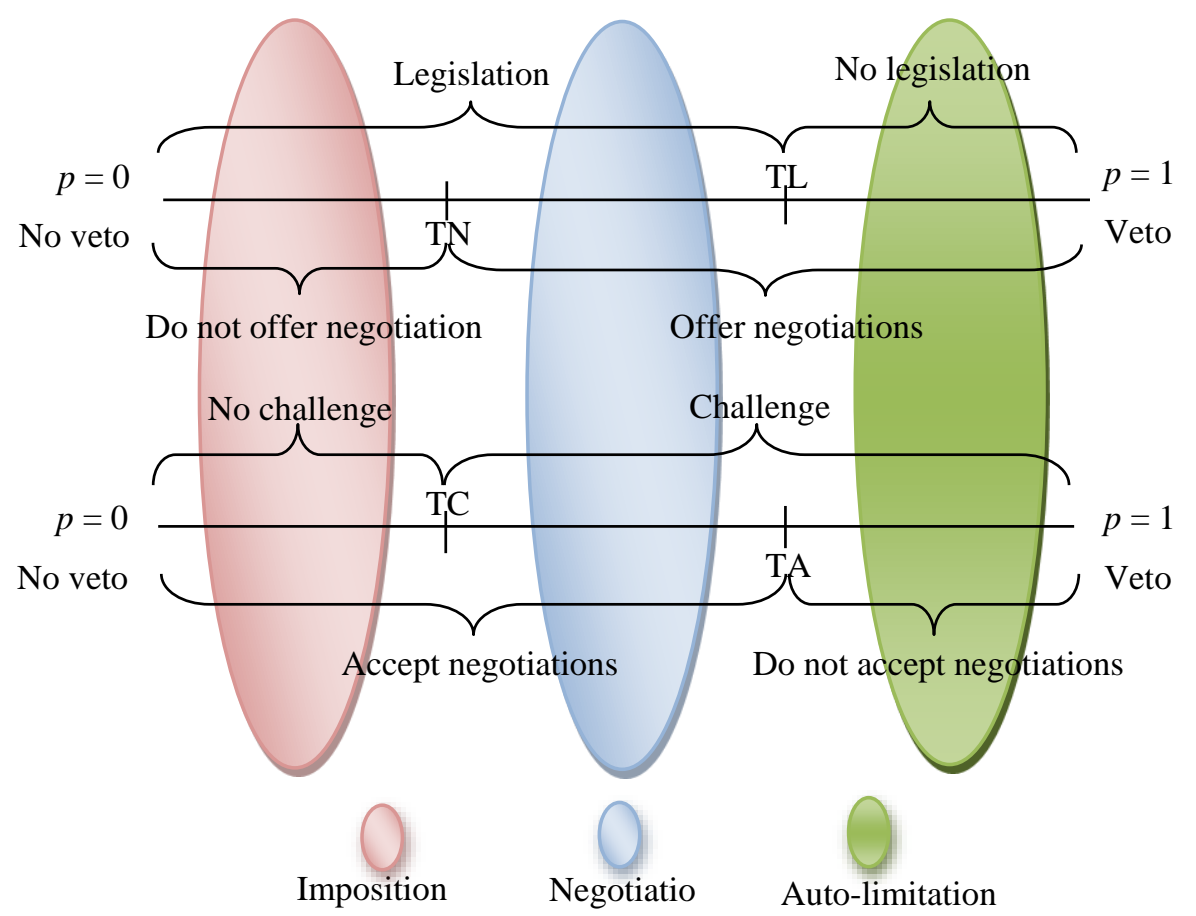

Figure 3. Equilibria resulting from the interaction between G1 and G2, when they predict different probabilities of a judicial veto.

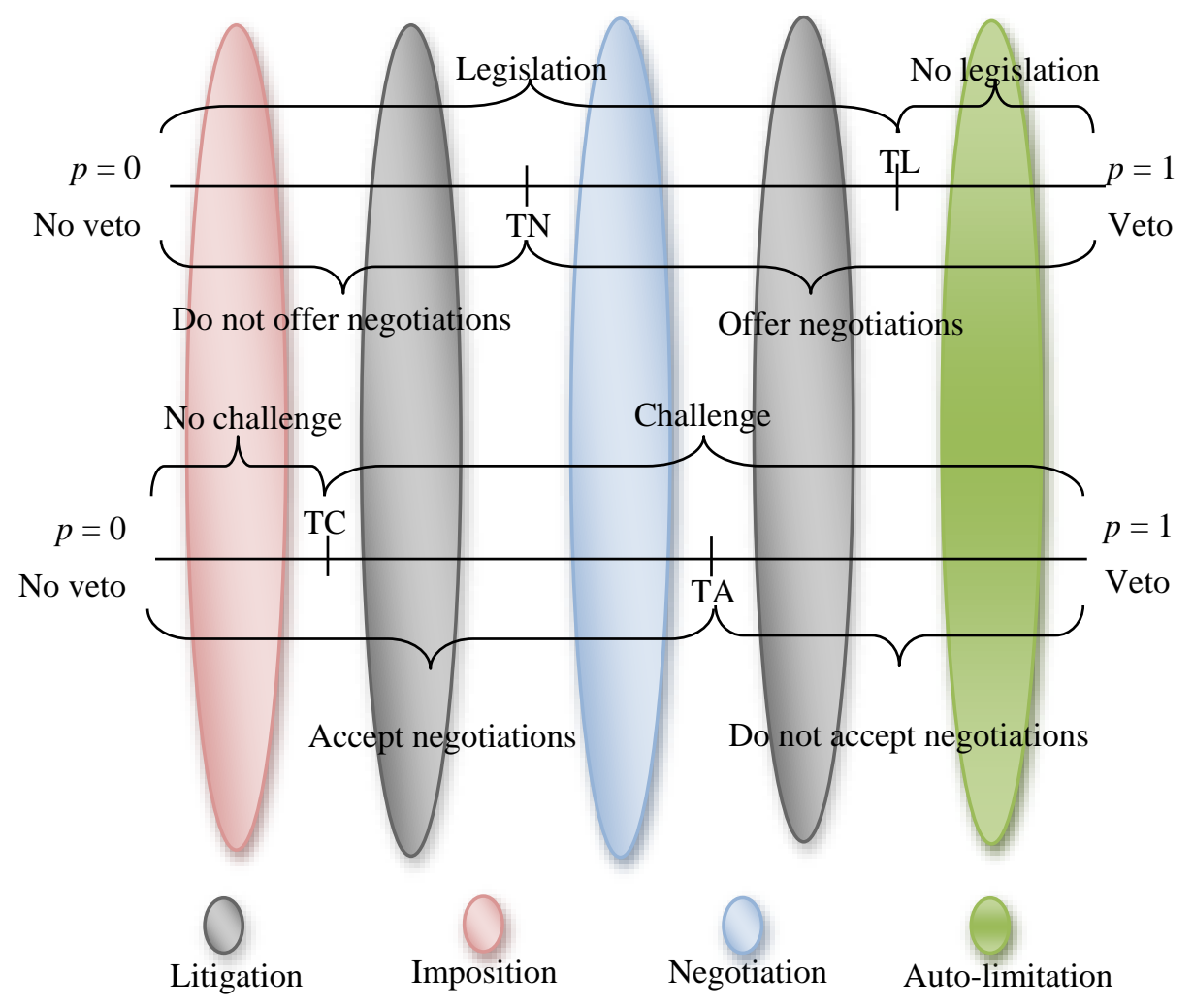




\section{Implications of the Model}

This article establishes the conditions under which the presence of judicial review may or may not enforce compliance with federalism. It explores the interactions between two governments in a minimal federation in anticipation that a controversial piece of legislation may face judicial review and a judicial veto. The model establishes six equilibria, depicting four distinct scenarios. Imposition, the ability to legislate on any issue regardless of the possible reaction of the opponents, takes place as the challenger's costs of losing a case or the likelihood of retaliation for raising a challenge grow. Auto-limitation, a government's decision to keep its policies within its constitutionally defined scope of powers, is more likely to occur as the legislator's costs of having its policies declared unconstitutional rise. Litigation takes place when the challenger's costs of activating judicial review are low and when there is uncertainty about whose side the court will take. Negotiation, understood as a mutual agreement between the policy-maker and its opponents to by-pass the court's involvement in a conflict, takes place when the benefits of negotiation outbalance the benefits of litigation for both players, including the government that would have won the case. The virtue of modeling the interactions between central and regional governments is that it provides a simplified understanding of the relationship between these four outcomes as a result of variation on the same limied factors.

Not all the equilibria that derive from this model result in compliance with the federal arrangement. Auto-limitation refers to a situation in which the anticipation of a judicial decision successfully deters governments from pursuing policies that transgress the federal arrangement. This is the only scenario, of the four predicted in this game, in which judicial review encourages compliance with federalism before overreaching legislation is enacted. Such a stabilizing outcome cannot always be expected from any of the other three predicted outcomes.

Litigation can only correct transgressing behaviors, but not prevent them. The model shows that litigation is most likely to take place with uncertainty-when there is no well-defined body of jurisprudence to guide alternative strategies to the governments in conflict. Whether the challenged law usurps another government's powers will not be known until the court makes a ruling, and the transgression will be valid until then. ${ }^{25}$ To the extent that it takes years before a piece of legislation is reviewed, governments benefit from a transgression while the case is pending.

Imposition takes place when a federal transgression is not challenged in court because potential plaintiffs fear a sufficiently large cost if they engage in litigation. As long as their opponents are too hesitant to litigate, legislators are able to pursue policies beyond their scope of powers. If this is the case, the availability of judicial review does not provide incentives for compliance with federalism.

Negotiation, while often seen as a great accomplishment in contentious federal settings, often implies a mutually agreed transgression. It could be argued that an agreement between legislators and their opponents to transgress the federal arrangement is not a transgression, or a mild one at best. Such agreements are temporary and $a d$ hoc, since they do not carry future obligations. It could also be said that negotiations to by-pass the court, and to extend a government's powers temporarily while compensating another, introduce flexibility in the federal arrangement. However, precisely because these agreements are ephemeral and do not have an impact in the court's future constitutional interpretations

${ }^{25}$ This is the case unless the overreaching government finds incentives to ignore the court's ruling-which is beyond the scope of this paper and theorized in Vanberg [29,33], Carubba, Gabel and Hankla [34]. 
about the federal division of powers, these negotiations do not produce long-standing, far-reaching reforms, nor change in an incremental but consistent direction. However, not all governments affected by the transgression are equally able to engage in negotiations. If legislators had to dissuade every government from challenging their policy in court, the transgression would indeed be a decision to which all representative governments agree upon. However, since not all governments have equal access to court (due to Imposition), the opportunity to negotiate and voluntarily accept another government's overreaching policies varies across the board. To the extent that some opponents can be deterred from going to court they will have to accept another government's encroachment and expect nothing in return. Therefore, negotiated transgressions may lead to extra-constitutional power asymmetries.

Optimistic views of what courts can do for federalism often give for granted judicial review as a successful deterrent of opportunistic behaviors. This article presents alternative scenarios in which the presence of the court enables transgressions to take place. Only empirical evidence will determine which of the four outcomes discussed here happens most often. The aim of this article is, however, to check for more than the one possible outcome presumed in most of the literature. In determining the conditions under which each strategy is more likely to occur, these findings help develop testable hypotheses for empirical research. For instance, in federations with few regional parties, imposition will be common since the central and regional governments will often share party label. Litigation is more likely to take place when constitutions are new, since their meaning will be ambiguous and there is no consolidated interpretation. As jurisprudence develops, governments will switch strategies leading to auto-limitation or negotiation, depending on whether legislators have something to exchange. Given that both levels of governments interact with each other repeatedly, I would anticipate negotiation to occur more frequently than auto-limitation. Overall, this article suggests that the role of courts in federal systems should not be expected to be the same in all federations and it depicts the conditions under which their role may vary. This may be an intuitive expectation, but one that is certainly overlooked in the literature.

The findings in this article also have consequences for our understanding of federalism. They challenge the prevalent distinction between dual federalism and cooperative federalism, which usually presented as incompatible approaches to how federations work. Dual (or juridical) federalism portrays the relationship between governments in a federation as a zero-sum-game, in which the powers allocated to one level of government are exclusive and in detriment of the jurisdiction of the other, and where the courts' job is to set the line between them. Cooperative federalism conceives intergovernmental relations as fluid interactions promoted by multilateral institutions, and as systems where the powers of each government may overlap or build on each other. Yet, my findings suggest that the dynamics of a minimalist federation, which is often characterized as a dual federation, create opportunities and incentives for cooperation. After all, negotiations result from the anticipation of a judicial ruling. Finally, this discussion also questions the presumption that cooperation is always beneficial for federalism, since negotiations may result from mutual willingness to transgress the federal arrangement and at the expense of governments in weaker bargaining positions. 


\section{Acknowledgments}

I am grateful to Mario Chacón, Leonid Peisakhin and William Ferguson for their careful readings and insightful comments to early drafts of this article. I benefited enormously from the feedback received at the Comparative Politics Workshop at Yale University, where this project took shape, and from the valuable suggestions from the anonymous reviewers for this journal. All errors, interpretations and omissions remain mine alone.

\section{Appendix}

\section{Proof of the Six Pure-Strategy Perfect Bayesian Equilibria of the Game}

Figure A1. Extensive form game of Imperfect Information Interaction between government units in a federation.

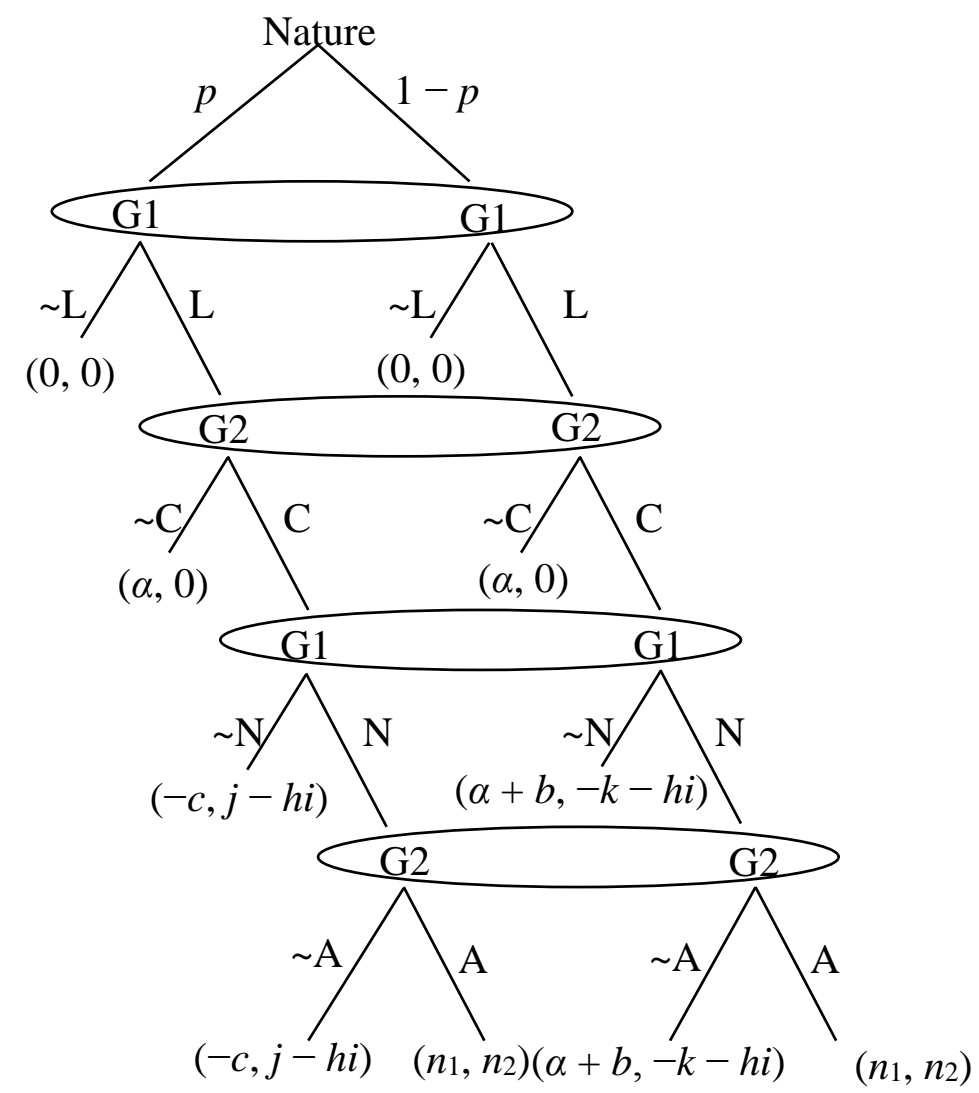

1. Consider the last stage of the game, in which G2 must respond to G1's offer to negotiate.

$\mathrm{EU}_{\mathrm{G} 2}(\mathrm{~A})=n_{2}$

$\mathrm{EU}_{\mathrm{G} 2}(\sim \mathrm{A})=p(j-h i)+(1-p)(-k-h i)$-this is the same as the utility of a challenge.

$\mathrm{G} 2$ will choose to accept negotiations if:

$\operatorname{EUG} 2(\mathrm{~A})>\operatorname{EUG} 2(\sim \mathrm{A})$

$n_{2}>p(j-h i)+(1-p)(-k-h i) \rightarrow p<\left(n_{2}+k+h i\right) /(j+k)$-which is identified TA. 
2. Consider G1 at the negotiation stage, in which G1 decides whether to offer negotiations or not.

Case I. If $p<\left(n_{2}+k+h i\right) /(j+k)$-i.e., G2 will accept to negotiate.

$\mathrm{EU}_{\mathrm{G} 1}(\mathrm{~N})=n_{1}$

$\mathrm{EU}_{\mathrm{G} 1}(\sim \mathrm{N})=(-c) p+(\alpha+b)(1-p)$

G1 will offer negotiations if:

$\mathrm{EU}_{\mathrm{G} 1}(\mathrm{~N})>\mathrm{EU}_{\mathrm{G} 1}(\sim \mathrm{N})$

$n_{1}>(-c) p+(\alpha+b)(1-p) \rightarrow p>\left(\alpha+b-n_{1}\right) /(\alpha+b+c)$ - which is TN.

Case II. If $p>\left(n_{2}+k+h i\right) /(j+k)-i . e ., \mathrm{G} 2$ will not accept to negotiate.

G1 will be indifferent because, under this condition, $\mathrm{EU}_{\mathrm{G} 1}(\mathrm{~N})=\mathrm{EU}_{\mathrm{G} 1}(\sim \mathrm{N})$.

3. Consider G2 at the challenging stage. It has to decide whether to challenge another government's policy or not.

Case I. If $p<\left(\alpha+b-n_{1}\right) /(\alpha+b+c)$-i.e., G1 will not offer negotiations.

$\mathrm{EU}_{\mathrm{G} 2}(\sim \mathrm{C})=0$

$\mathrm{EU}_{\mathrm{G} 2}(\mathrm{C})=p(j-h i)+(1-p)(-k-h i)$

G2 will challenge if:

$\mathrm{EU}_{\mathrm{G} 2}(\mathrm{C})<\mathrm{EU}_{\mathrm{G} 2}(\sim \mathrm{C})$

$p(j-h i)+(1-p)(-k-h i)<0 \rightarrow p>(k+h i) /(j+k)$ —which above was TC.

Case II. If $p>\left(\alpha+b-n_{1}\right) /(\alpha+b+c)$ and $p>\left(n_{2}+k+h i\right) /(j+k)$-i.e., G1 offers negotiations and $\mathrm{G} 2$ does not accept. Result is same as above.

Case III. If $p>\left(\alpha+b-n_{1}\right) /(\alpha+b+c)$ and $p<\left(n_{2}+k+h i\right) /(j+k)$-i.e., G1 offers negotiations and $\mathrm{G} 2$ accepts.

$\mathrm{EU}_{\mathrm{G} 2}(\mathrm{C})=n_{2}$

$\mathrm{EU}_{\mathrm{G} 2}(\sim \mathrm{C})=0$

$\mathrm{G} 2$ will always challenge because $n_{2}>0$.

4. Consider G1 at the legislating stage. It decides whether to legislate or not.

Case I. If $p<(k+h i) /(j+k)$-i.e., G2 does not challenge.

$\mathrm{EU}_{\mathrm{G} 1}(\mathrm{~L})=\alpha$

$\mathrm{EU}_{\mathrm{G} 1}(\sim \mathrm{L})=0$

G1 always legislates, because $\alpha>0$.

Case II. If $p>(k+h i) /(j+k)$ and $p<\left(\alpha+b-n_{1}\right) /(\alpha+b+c)$-i.e., G2 challenges, and G1 does not negotiate.

$\mathrm{EU}_{\mathrm{G} 1}(\mathrm{~L})=(-c) p+(\alpha+b)(1-p)$

$\mathrm{EU}_{\mathrm{G} 1}(\sim \mathrm{L})=0$

G1 will legislate if:

$\mathrm{EU}_{\mathrm{G} 1}(\mathrm{~L})>\mathrm{EU}_{\mathrm{G} 1}(\sim \mathrm{L})$

$(-c) p+(\alpha+b)(1-p)>0 \rightarrow p<(\alpha+b) /(\alpha+b+c)$-which above was presented as TL. 
Case III. If $p>(k+h i) /(j+k)$ and $p>\left(\alpha+b-n_{1}\right) /(\alpha+b+c)$ and $p<\left(n_{2}+k+h i\right) /(j+k)$ i.e., G2 challenges, and G1 offers negotiation and G2 accepts.

$\mathrm{EU}_{\mathrm{G} 1}(\mathrm{~L})=n_{1}$

$\mathrm{EU}_{\mathrm{G} 1}(\sim \mathrm{L})=0$

G1 will always legislate because $n_{1}>0$.

Case IV. If $p>(k+h i) /(j+k)$ and $p>\left(\alpha+b-n_{1}\right) /(\alpha+b+c)$ and $p>\left(n_{2}+k+h i\right) /(j+k)-$ i.e., G2 challenges, and G1 offers negotiation and G2 does not accept. Given same payoffs, results are the same as in Case II.

\section{Conflicts of Interest}

The author declares no conflict of interest.

\section{References}

1. Bednar, J. The Robust Federation; Cambridge University Press: Cambridge, UK, 2009.

2. Filippov, M.; Ordeshook, P.C.; Shvetsova, O.V. Designing Federalism: A Theory of Self-Sustainable Federal Institutions; Cambridge University Press: London, UK, 2001.

3. Bednar, J.; Eskridge, W.N., Jr.; Ferejohn, J. A political theory of federalism. In Constitutional Culture and Democratic Rule; Ferejohn, J., Riley, J., Rakove, J.N., Eds.; Cambridge University Press: New York, NY, USA, 2001; pp. 223-267.

4. Rogers, J. Information and judicial review: A signaling game of legislative-judicial interaction. Am. J. Polit. Sci. 2001, 45, 84-99.

5. Dahl, R. Federalism and democratic process. In Democracy, Identity and Equality; Norwegian University Press: Oslo, Norway, 1986; pp. 114-126.

6. Linz, J.J. Democracy, Multinationalism and Federalism, Estudio/Working Paper 1997/103; Centro de Estudios Avanzados en Ciencias Sociales: Madrid, Spain, 1997.

7. Elazar, D.J. Exploring Federalism; University of Alabama Press: Tuscaloosa, AL, USA, 1987.

8. Kramer, L. Understanding federalism. Vanderbilt Law Review 1994, 47, 1485.

9. Kramer, L. Putting the politics back into the political safeguards of federalism. Columbia Law Rev. 2000, 100, 215-293.

10. De Figueiredo, R.J.P.; Weingast, B. Self-enforcing federalism. J. Law Econ. Organ. 2005, 21, $13-135$.

11. Watts, R.L. Comparing Federal Systems; McGuill-Queen's University Press: Kingston, ON, Canada, 2008.

12. Bulman-Pozen, J.; Gerken, H.K. Uncooperative federalism. Yale Law J. 2009, 118, 1256-1310.

13. Pursley, G.B. Preemtion in Congress. Ohio State Law J. 2010, 71, 253-349.

14. Pursley, G.B. The campaign finance safeguards of federalism. Emory Law J. 2014, 63, 781-855.

15. Ryan, E. Negotiating federalism. Boston Coll. Law Rev. 2011, 52, 1-136.

16. Wechsler, $\mathrm{H}$. The political safeguards of federalism: The role of the states in the composition and selection of the national government. Columbia Law Rev. 1954, 54, 543-560.

17. Schapiro, R. Polyphonic federalism: Towards the protection of fundamental rights. Chicago University Press: Chicago, IL, USA, 2009. 
18. Baker, L.A.; Young, E.A. Federalism and the double standard of judicial review. Duke Law J. 2001, 51, 75-128.

19. Baker, L.A. Putting the safeguards back into the political safeguards of federalism. Villanova Law Rev. 2001, 46, 950-973.

20. Smith, P.J. Federalism, instrumentalism and the legacy of the Rehnquist Court. George Wash. Law Rev. 2006, 74, 906.

21. Cross, F. Realism about federalism. N. Y. Univ. Law Rev. 1999, 74, 1304.

22. Rogers, J.; Vanberg, G. Judicial advisory opinions and legislative outcomes in comparative perspective. Am. J. Polit. Sci. 2002, 46, 379-397.

23. Bednar, J. Judicial predictability and federal stability: Strategic consequences of institutional imperfection. J. Theor. Polit. 2005, 16, 423-446.

24. Stone-Sweet, A. Governing with Justices. Oxford University Press: New York, NY, USA, 1998.

25. Stone, A. The Birth of Judicial Politics in France: The Constitutional Council in Comparative Perspective. Oxford University Press: New York, NY, USA, 1992.

26. Vanberg, G. Legislative-judicial relations: A game-theoretic approach to judicial review. Am. J. Polit. Sci. 2001, 45, 346-362.

27. Vanberg, G. Abstract judicial review, legislative bargaining, and policy compromise. J. Theor. Polit. 1998, 10, 299-326.

28. Blair, P.M. Federalism and Judicial Review in West Germany; Clarendon Press: Oxford, UK, 1981.

29. Miley, T.J. Nacionalismo y Política Lingüística: El Caso de Cataluña; Centro de Estudios Políticos y Constitucionales: Madrid, Spain, 2006.

30. Ley 39/2006, de 14 de diciembre, de Promoción de la Autonomía Personal y Atención a las personas en situación de dependencia. Available online: https://www.boe.es/buscar/doc.php?id=BOE-A2006-21990 (accessed on 17 November 2014).

31. Consell de Garanties Estatutàries. 2007. Dictàmen 279, de 29 de gener de 2007. Available online: https://www.cge.cat/contingut.php?id_pagina=17\&start=10 (accessed on 17 November 2014) (in Catalan).

32. Aja, E. La Novedad de la Ley de Dependencia. El Periódico, 12 December 2007, 13. (In Spanish)

33. Muñoz, J. El Gobierno Catalán Cree Como el Vasco Que la Ley de Dependencia Invade sus Competencias. El Correo Vasco 1 February 2007. Available online: http://www.elcorreo.com/ vizcaya/prensa/20070201/otros/gobierno-catalan-cree-como_20070201.html (accessed on 17 November 2014) (in Spanish).

34. Bedolla, J.G. El Negocio de las Dependencias. El País, 7 September 2007, Available online: http://elpais.com/diario/2007/07/09/sociedad/1183932002_850215.html (accessed on 17 November 2014) (in Spanish).

35. Vanberg, G. The Politics of Constitutional Review in Germany; Cambridge University Press: Cambridge, UK, 2005.

36. Stone-Sweet, A. Path dependence, precedent and judicial power. In On Law, Politics and Judicialization; Shapiro, M., Stone-Sweet, A., Eds.; Oxford University Press: Oxford, UK, 2002; pp. 112-135.

37. Shapiro, M. The giving reasons requirement. In On Law, Politics and Judicialization; Shapiro, M., Stone-Sweet, A., Eds.; Oxford University Press: Oxford, UK, 2002; pp. 228-257. 
38. Bailey, M.A.; Maltzman, F. The Constrained Court: Law, Politics and the Decisions Justices Make; Princeton University Press: Princeton, NJ, USA, 2011.

39. Segal, J.A.; Spaeth, H.J. The Supreme Court and the Attitudianl Model Revisited; Cambridge University Press: Cambridge, UK, 2002.

40. Baum, L. Judges and Their Audience: A Perspective on Judicial Behavior; Princeton University Press: Princeton, NJ, USA, 2006.

41. Hansford, T.G.; Spriggs, J.F. The Politics of Precedent on the U.S. Supreme Court; Princeton University Press: Princeton, NJ, USA, 2006.

42. Acemoglu, D.; Robinson, J.A. Economic Origins of Democracy and Dictatorship; Cambridge University Press: Cambridge, UK, 2006.

43. Hayo, B.; Voigt, S. Explaining de facto judicial independence. Int. Rev. Law Econ. 2007, 27, 269-290.

44. Helmke, G. Courts under Constraints: Judges, Generals, and Presidents in Argentina; Cambridge University Press: New York, NY, USA, 2005.

45. Carubba, C.; Gabel, M.; Hankla, C. Judicial behavior under political constraints: Evidence from the European Court of Justice. Am. Polit. Sci. Rev. 2008, 102, 435-452.

46. Ackerman, B. Constitutional politics/constitutional law. Yale Law J. 1989, 99, 453-547.

47. National Federation of Independent Business v. Sebelius, 567 U.S. 2012. Available online: http://www.supremecourt.gov/opinions/11pdf/11-393c3a2.pdf (accessed on 18 November 2014).

48. Epstein, L.; Knight, J.; Martin, A.D. The supreme court as national policy maker. Emory Law J. 2001, 50, 583-611.

49. Epp, C. The Rights Revolution: Lawyers, Activists and the Supreme Courts in Comparative Perspective; University of Chicago Press: Chicago, IL, USA, 1998.

50. Boyeller, N. The influence of political parties on policy coordination. Governance 2011, 24, 469-494.

51. Nugent, J.D. Safeguarding Federalism: How Sattes Protect Their Interests in National Policymaking; University of Oklahoma Press: Norman, OK, USA, 2009.

52. Riker, W.H. Federalism: Origin, Operation and Significance; Little Brown: Boston, MA, USA, 1964.

53. Sala, G. Federalism without adjectives in Spain. Publius 2014, 44, 109.

54. Alfonso, L. Leaking Accountability on the way to federalism? The Case of Spain. Presented at the Council for European Studies Conference, Montréal, QC, Canada, 15-17 April 2010.

(C) 2014 by the authors; licensee MDPI, Basel, Switzerland. This article is an open access article distributed under the terms and conditions of the Creative Commons Attribution license (http://creativecommons.org/licenses/by/4.0/). 